\title{
Reflexões sobre os conceitos de saúde e doença e suas implicações
}

CZERESNIA, D.; MACIEL, E.M.G.S.; OVIEDO, R.A.M. (Org.).

Os sentidos da saúde e da doença.

Rio de Janeiro: Editora Fiocruz; 2013.119 p.

I Ana Maria Canesqui I

${ }^{1}$ Faculdade de Ciências Médicas, Universidade de Campinas. Campinas-SP, Brasil (anacanesqui@hotmail.com).

DOI: http://dx.doi.org/10.1590/S0103-73312016000100020

É bem-vinda a reflexão crítica dos conceitos de saúde e doença à formação e prática dos profissionais de saúde que reconhece a historicidade, mudanças e limites dos saberes hegemônicos. Trata-se de um assunto que preocupa os pesquisadores do campo da Saúde Coletiva, cujo debate, análises e propostas reformuladoras dos saberes e modelos de intervenção não são novos e continuam desafiadores.

Os pensadores da Medicina Social no Brasil, na década de 1970, abriram espaço à densa reflexão epistemológica, histórica e sociológica daqueles conceitos no modelo biomédico, dos determinantes sociais, políticos e econômicos do processo saúde e doença, do trabalho médico, à análise crítica da política de saúde, vigente naquele contexto, modificada, posteriormente, para formar o Sistema Único de Saúde (SUS), justo e igualitário, ancorado nos direitos à saúde e à cidadania.

$\mathrm{O}$ assunto instiga e Os sentidos da saúde e da doença quer sensibilizar os profissionais de saúde para outras maneiras de olhar a saúde e doença que na sua introdução considera os contextos sócio-históricos, querendo abalar o poder das verdades produzidas e reproduzidas nos espaços institucionais da saúde, que minimizam a experiência cotidiana do adoecer.

Os cinco capítulos discutem os sentidos da saúde; as transformações dos conceitos de saúde e doença; a prevenção das doenças e a promoção da saúde; 
o discurso do risco e as teorias da doença. Sugerem leituras de autores clássicos, como Canguilhem (1985), Foucault (1987), Rosen (1994), Entralgo (1982) e dos nacionais que contribuíram com estas reflexōes: Camargo Jr (2003), Almeida Filho (2911), Czeresnia (2012) e outros.

A coletânea oferece um bom roteiro para os iniciantes no assunto. Entre seus organizadores está Dina Czeresnia médica, doutora em Saúde Pública, pesquisadora do Departamento de Epidemiologia e Métodos Quantitativos em Saúde da Escola Nacional de Saúde Pública Sérgio Arouca (ENSP). Suas publicações sobre o saber epidemiológico; os conceitos de saúde e doença; a vida na nova biologia; a promoção da saúde e prevenção são bastante conhecidos.

Elvira Maria Godinho de Seixas Maciel, médica, doutora em Filosofia, é pesquisadora daquele departamento, e o odontólogo Rafael Antonio Malagón Oviedo, bolsista da Capes na ENSP, é professor do Departamento de Saúde Coletiva da Faculdade de Odontologia da Universidade Nacional de Colômbia.

$\mathrm{O}$ primeiro capítulo mostra que os sentidos da saúde não se reduzem à construção científica, variando as concepções integradas às condições concretas de existência e às experiências singulares. Reporta-se a Canguilhem sobre o normal e o patológico, à relatividade dos conceitos de saúde e doença e às diferenças entre os conceitos científicos e as experiências vividas. O capítulo agrega reflexôes sobre a saúde e morte; a intervenção das tecnologias médicas no prolongamento da vida e os dilemas éticos relacionados e as possibilidades de convivência criativa e normativa com os adoecimentos crônicos. Esta última questão impõe novas reflexôes às práticas de cuidado, instauradas pelas intervenções biomédicas, defendendo a importância de ouvir os adoecidos sobre as formas de pensar e agir nos adoecimentos e sofrimentos de longa duração.

O capítulo dois é amplo. Reconstrói, historicamente, os conceitos de saúde e doença, suas mudanças, a dinâmica dos processos de adoecimento e das intervenções terapêuticas nas etapas históricas do Ocidente (Antiguidade Clássica, Idade Média, Renascimento e Pós-Renacimento). Aborda as mudanças, antecedentes à formação da racionalidade biomédica no século XVII e à cientificidade da medicina, no século XIX; debate as teorias do contágio e da transmissão das epidemias, nos séculos XVII e XIX e a constituição da Higiene e Saúde Pública; da Clínica; Epidemiologia e Bacteriologia. 
O capítulo três também é histórico. Aborda, no período de 1920 a 1950, a formação da Medicina Preventiva inglesa e norte-americana, destacando Leavell e Clark (1976) e o modelo da história natural da doença, considerando após a década de 1950 as propostas de prevenção das doenças, no contexto das mudanças demográficas e epidemiológicas nos países industrializados, onde se destacam as doenças crônicas que estimularam a aliança da clínica com a epidemiologia, ao lado do modelo canadense de promoção da saúde.

O capítulo se encerra com a promoção da saúde e as mudanças nos estilos de vida, repensadas sob o marco dos determinantes sociais em saúde, interessado nas desigualdades e na falta da equidade em saúde. A reflexão crítica sobre o discurso do risco interessa ao quarto capítulo sobre sua interferência na produção de tecnologias, na organização institucional e expansão da ideologia individualista. Os modelos de análise dos riscos epidemiológicos invadiram a Epidemiologia e a Saúde Pública, afirmando os autores que:

[...] os estudos voltam-se, tanto para a determinação do esquema causal das doenças, quanto para a avaliação das tecnologias, no intuito de embasar a incorporação e continuidade da utilização de procedimentos técnicos na área da saúde.

O quinto capítulo sobre as teorias da doença aborda a orgânica, usada pela biomedicina e preconizada pela anatomoclínica, excluindo a dimensão simbólica; a teoria psicanalítica para as doenças mentais, a psicologia e as neurociências reforçam o modelo biomédico. Preocupaçôes da biomedicina com a etiologia causal buscaram controlar e intervir nas doenças, enquanto o desenvolvimento atual da biologia molecular trouxe mudanças importantes nos diagnósticos, nas intervenções e no conhecimento.

Os autores exemplificam doenças não enquadradas nos parâmetros causais usuais, demandantes de novas explicações. Persistem lacunas no conhecimento científico na explicação da etiologia de enfermidades, como a fibrimialgia, cólon irritável, depressão e várias síndromes crônicas, que impõem sofrimentos físicos e morais aos adoecidos. Além da importância do saber biomédico e de suas tecnologias, há outros saberes e práticas, acionados pela população para tratar as enfermidades.

As considerações finais retomam os conteúdos de cada capítulo, apontando a inexistência de conclusão definitiva para o debate. Sugerem construir a 
interdisciplinaridade, desde que as circunstâncias da vida humana geram problemas de saúde e doença e a experiência da enfermidade não se esgota na compreensão biomédica. $\mathrm{O}$ debate não prescinde das contribuiç̧ões das ciências sociais e humanas; suscita explicações mais complexas e ecológicas da relação homem/mundo. A coletânea é pequena, porém sintética nas ideias e reflexōes, recomendando-se sua leitura aos iniciantes e interessados em compreender os sentidos da saúde e da doença.

\section{Referências}

ALMEIDA FILHO, N. O que é saúde? Rio de Janeiro: Fiocruz, 2011.

CAMARGO Jr., KR. Biomedicina, Saber \& Ciência. Uma abordagem crítica. São Paulo: Hucitec, 2003.

CANGUILHEM, G. O normal e o patológico. Rio de Janeiro: Forense Universitária, 1995.

CZERESNIA, D. Categoria vida: reflexôes para uma nova biologia. Rio de Janeiro: Fiocruz, 2012.

ENTRALGO, P. L. História universal da medicina. Barcelona: Salvar, 1982.

FOUCAULT, M. O nascimento da clínica. Rio de Janeiro: Forense Universitária, 1987.

LEAVELL, S.; CLARCK, E. G. Medicina Preventiva. São Paulo: McGraw-Hill, 1976.

ROSEN, G. Uma história da Saúde Pública. São Paulo: Hucitec, 1994. 